\title{
Kapitał społeczny i jego wpływ na efektywność rozwoju regionu na przykładzie Małopolski
}

\section{Social Capital and its Impact on the Effectiveness of Region's Development Based on the Example of Małopolska}

\begin{abstract}
Streszczenie: Literatura specjalistyczna w sposób jednoznaczny wskazuje na występowanie wielu czynników mających znaczenie w rozwoju regionów, zarówno ze sfery ekonomicznej, jak i pozaekonomicznej. Celem artykułu jest przegląd prac źródłowych dotyczących rozwoju i atrakcyjności regionu, ze szczególnym uwzględnieniem prac na temat kapitału społecznego, który jest jedną z ważniejszych determinant, mających wpływ na rozwój społeczno-gospodarczy danego obszaru w różnych układach przestrzennych. W niniejszej analizie dokonano próby ukazania wpływu człowieka na potencjał i rozwój województwa małopolskiego. Autorka zadała sobie pytanie, czy ten rodzaj kapitału jest i może być w przyszłości czynnikiem, który pobudza rozwój społeczno-ekonomiczny regionu. Z przeprowadzonych analiz wynika, iż potencjałem województwa małopolskiego są młodzi ludzie. Województwo to od kilku lat jest w czołówce województw pod względem liczby studentów przypadającej na 10 tys. osób w wieku 19-24 lat. Wskaźnik aktywności zawodowej osób młodych (15 i więcej lat) w 2010 r. wynosił $54,7 \%$, a w $2015-55,5 \%^{1}$. Przeprowadzone badania dowiodły, że kapitał społeczny łączy się z aspektami gospodarczymi, a także $\mathrm{z}$ aspektami niezwiązanymi w sposób bezpośredni z gospodarką w regionie.
\end{abstract}

\begin{abstract}
Social capital is one of the most important determinants that have an impact on the socio-economic development of a given region in various spatial systems. Specialist literature clearly indicates the presence of various crucial factors in the development of regions. We include both the economic and non-economic spheres. The purpose of the article is to review the source work, including development and the attractiveness of the region, with particular emphasis on social capital. This analysis attempts to show the human impact on the potential and development of the Małopolskie voivodeship. The author asked herself if this kind of capital is and may in the future be a factor that stimulates the socio-economic development of the region. The analysis shows that the potential of Małopolska is young people. For several years this area has been one of the top voivodeships, taking into account the number of students per 10,000 people aged 19-24. Activity rate of young people (15 and older): in 2010 it amounted to $54.7 \%$, and in 2015 to $55.5 \%^{1}$. The conducted research proved that social capital is connected with economic aspects, but also not directly related to economy in the region.
\end{abstract}

\footnotetext{
${ }^{1}$ Dane na podstawie: Główny Urząd Statystyczny (2016).
} 
Słowa kluczowe: efektywność; kapitał społeczny; potencjał; region

Keywords: efficiency; potential; social capital; region

Otrzymano: 19 października 2017

Received: 19 October 2017

Zaakceptowano: 28 maja 2018

Accepted: 28 May 2018

Sugerowana cytacja/Suggested citation:

Borgiasz, M. (2018). Kapitał społeczny i jego wpływ na efektywność rozwoju regionu na przykładzie Małopolski. Przedsiębiorczość - Edukacja [Entrepreneurship - Education], 14, 49-61. DOI: $10.24917 / 20833296.14 .4$

\section{Wstęp}

Termin „kapitał społeczny” w ostatnich latach stał się bardzo popularny. Przyczyniła się do tego publikacja R. Putnama, poświęcona różnicom w rozwoju gospodarczym między północną a południową częścią Włoch. Dysonans w rozwijaniu się tych regionów był związany m.in. z jakością więzi społecznych na danym obszarze. Putnam odniósł kapitał społeczny do cech, które pozwalają na aktywną i przedsiębiorczą koordynację działań zmierzających do rozwoju regionu. Tymi cechami są m.in.: zaufanie, normy i zasady zwiększające energię społeczeństwa oraz jego działanie. Kapitał społeczny jest efektywny i wpływa na przedsiębiorczość, umożliwia też osiągnięcie takich celów, których nie udałoby się wypracować bez jego udziału (Putnam, 1995).

Rozwój efektywności i aktywności regionalnej związany jest nie tylko ze ściśle określonymi regułami instytucji, ale także z normami współpracy, prowadzonej często przez organizacje na zasadzie dobrowolności. I tu pojawia się kapitał pomostowy. Dotyczy on zaufania oraz umiejętności współdziałania osób, które się nie znają i które nie są związane bezpośrednimi kontaktami. Jest on połączony $\mathrm{z}$ aktywnością $\mathrm{w}$ sytuacjach realizowania wspólnych określonych celów (Zarycki, 2008). Kapitał pomostowy jest koniecznym bodźcem rozwoju gospodarczego i przedsiębiorczości regionu. Jest gwarantem odpowiedniego funkcjonowania struktur społecznych.

Kapitał społeczny to również przedsiębiorczość. Zjawisko to jest zespołem cech, dążeń, aspiracji, aktywności oraz działań progresywnych (Piróg, 2016). W rozwoju regionu aktywność przedsiębiorcza jest procesem złożonym, wynikającym z różnych zależności występujących na płaszczyźnie region - przedsiębiorczość. Poziom postępu i progresji regionu może stymulować przedsiębiorczość, a z drugiej strony zachowania przedsiębiorcze wpływają na modelowanie i organizowanie rozwoju określonego regionu (Zygmunt, 2015).

Rozważania teoretyczne na temat przedsiębiorczości i jej wpływu na rozwój regionu były prowadzone m.in. przez D.B. Audretscha i M. Fritscha, P. Bennewortha, R. Hugginsa oraz N. Williamsa (Audretsch, Fritsch, 2002; Benneworth, 2004; Huggins, Williams, 2011). Natomiast w Polsce badaniami tych zjawisk zajmuje się m.in. A. Klasik (Klasik, 2006). Te prace oraz analizy mają głównie charakter teoretyczny. W takiej sytuacji podjęcie badań empirycznych skierowanych na ukazanie wpływu przedsiębiorczości na rozwój regionalny w Polsce, uwzględniający kapitał społeczny, wydaje się prestiżowe. 
Celem niniejszego artykułu jest, przy zastosowaniu metody studiów literatury:

- przedstawienie wpływu kapitału społecznego na efektywność regionu w ujęciu teoretycznym,

- zaprezentowanie danych statystycznych oraz wybranych mierników ukazujących rozwój regionu małopolskiego pod kątem kapitału społecznego.

\section{Przedsiębiorczość a rozwój regionalny}

Region funkcjonuje w określonym otoczeniu, na które oddziałuje i pod wpływem którego pozostaje. Literatura pokazuje, iż jednym z głównych czynników rozwoju regionalnego jest przedsiębiorczość. Według E. Skawińskiej, przedsiębiorczość odgrywa ważną rolę $\mathrm{w}$ asygnowaniu określonych zasobów regionu oraz tworzeniu jego nowych i ulepszonych elementów. Ważne jest też szukanie innowacji w już istniejącej konfiguracji społeczno-gospodarczej (Skawińska, 2009). W postępie regionalnym wyróżnia się trzy rodzaje przedsiębiorczości: przedsiębiorczość biznesową, publiczną i społeczną (Huczek, 2011). Każda $z$ nich porusza się swobodnie i racjonalnie, podejmując decyzje i działania związane $\mathrm{z}$ regionem. Proces rozwoju regionalnego powinien obejmować samorządy terytorialne, partnerstwo społeczne i uwarunkowania kulturowe (Huczek, 2011). Ogniwa te współcześnie wzajemnie na siebie oddziałują i tworzą nowe procesy w wielu zakresach oraz formach gospodarki. W każdym działaniu pojawiają się różne formy przedsiębiorczości, tworzące nowe układy różnorodnych potencjałów. M. Strużycki twierdzi, że przedsiębiorczość regionalna jest to forma interpretowania gospodarki regionu, która w połączeniu z atrakcyjnością i polityką może wpłynąć na tworzenie się nowych jednostek gospodarczych oraz popularyzowanie nowatorskich rozwiązań ekonomicznych. Dotyczy to firm, które funkcjonują w danym układzie administracyjnym, jak i władz administracyjno-samorządowych określonego regionu. Czynnikami, które rozwijają lub blokują przedsiębiorczość regionalną, są m.in.: demografia regionu, regionalne rynki pracy, struktura gospodarki, ranga kapitału ludzkiego, przedsiębiorstwa w regionie, zasoby mieszkaniowe i infrastruktura (Strużycki, 2011).

Przedsiębiorczość regionu koreluje z kapitałem społecznym. Liberalizm w podejmowaniu działań, otwartość na nowe inicjatywy oraz lojalność wpływają na poczynania przedsiębiorcze i rozwój regionalny.

Współcześnie przedsiębiorczość odnosi się do różnorodnych schematów działalności człowieka. Ważne są dynamika, kreatywność, skuteczność i wydajność różnych procesów. Obejmuje to zarówno organizacje życia społecznego, jak i organizacje publiczne i pozarządowe. Nowa przedsiębiorczość oparta jest na jednostkach i zespołach innowacyjnych, które tworzą nowatorską gospodarkę.

\section{Znaczenie kapitału społecznego w progresji regionu}

Jednym z ważniejszych zadań dla regionów w XXI w. jest układ gospodarki oparty na wiedzy, w której fundamentalne znaczenie ma kapitał społeczny. Po raz pierwszy koncepcja gospodarki opartej na wiedzy została rozważona przez F. Machlupa (Machlup, 1962). Jednak rozpowszechnił ją P. Drucker, który wprowadził pojęcie społeczeństwa wiedzy (Drucker, 1994). Podstawowym zasobem tego pojęcia stała się nauka dająca możliwość rozwoju oraz wzmocnienia zbiorowości. Zaś przekaźnikiem wiedzy jest wartość kapitału społecznego (Bartnik, 2016). 
Koncepcje kapitału społecznego w literaturze pojawiły się w XVII w. wprowadzone przez W. Petty'ego. W jego osądzie kompetencje człowieka są częścią kapitału stałego (Petty, 1699). Podobnie przedstawił to zagadnienie A. Smith, który uważał, że umiejętności i wykształcenie człowieka mają wpływ na efektywność pracy, a co za tym idzie - na bogactwo państwa (Smith, 1954). W myśl tych rozważań powstała teoria kapitału społecznego, zebrana w pracach takich badaczy, jak: J. Mincer, T. Schultz i G. Becker. Autorzy Ci zwrócili uwagę na znaczenie kapitału społecznego w odniesieniu do wynagrodzenia pracowników, które związane zaczęło być z edukacją i praktyką zawodową. Powstała hipoteza, która zakładała, iż doświadczenie, profesjonalizm i wiedzę można traktować jako postać kapitału, będącego źródłem wzrostu uposażenia. W 1962 r. G. Becker wprowadził termin „lokowanie w kapitał społeczny”, który ma wpływać na korzyści materialne. Jego zdaniem, nauka, praktyka i doświadczenie zawodowe oraz dbałość o zdrowie to elementy mające wpływ na zasoby ludzkie (Becker, 1962).

Według analiz problematyki kapitału duże znaczenie dla rozwoju człowieka ma jego otoczenie, czyli region. Wpływ miejsca odgrywa istotną rolę w potęgowaniu kapitału wiedzy. To, gdzie mieszkamy, uczymy się i żyjemy, określa się mianem kapitału początkowego. W wieku późniejszym kapitał tworzą doświadczenie i praktyka zawodowa oraz czynniki społeczne i kulturowe. Biorąc pod uwagę te okoliczności, S. Cote stwierdził, że stymulacja, nastawienie, potencjał oraz wiedza i umiejętności międzyludzkie są elementami kapitału społecznego, ale bardzo silnie powiązanymi z kulturą i zwyczajami, czyli $\mathrm{z}$ regionem (Bartnik, 2016).

Współcześnie pojęcie kapitału społecznego może być rozpatrywane w dwóch aspektach. Pierwszy z nich obejmuje kapitał jako wiedzę, wykształcenie i indywidualne kompetencje człowieka, które pomogą mu zrealizować określone zadania i cele (Bontis, 2002). Drugie ujęcie rozumiane jest jako zespół wszystkich cech psychofizycznych danej osoby. Wśród nich rozróżnia się: zdolności, wykształcenie, wiedzę, umiejętności, doświadczenie, a także stan zdrowia, aktywność społeczno-ekonomiczną oraz światopogląd (Florczak, 2007). Działalność społeczna oraz gospodarcza łączą się ściśle z regionem, w którym dana jednostka lub społeczeństwo funkcjonuje.

Zdaniem S.R. Domańskiego, kapitał społeczny w szerokim ujęciu jest zasobem wiedzy, kompetencji, predyspozycji oraz aktywności, które zawarte są w społeczeństwie. Ten rezerwuar oddziałuje na przyszłe spełnienie w aspekcie zawodowym oraz osobistym (Domański, 1993).

Kapitał społeczny ma niematerialny wymiar, który może wpływać na obszary jego wykorzystywania. Mimo to jest zasobem mobilnym, a przez przemieszczanie się może stanowić zaletę lub zagrożenie dla danego regionu.

Omówione przykłady określenia kapitału społecznego pozwalają na połączenie go z rozwojem regionu. Zasób ten ma związek $\mathrm{z}$ daną jednostką, która funkcjonuje w określonym obszarze. Kapitał społeczny w regionie może prowadzić do przemieszczania się czynników produkcji. Wynikać to może z otwartości regionów, która daje możliwość krążenia elementów produkcji pomiędzy terytoriami. Przemieszczanie się ludzi ma związek z poziomem kapitału społecznego. Większa mobilność wynika z wyższego jakościowo elementu ludzkiego i zwiększa aktywność między regionami. Tam, gdzie można uzyskać wyższe zarobki, obserwuje się napływ ludzi, a w odwrotnej sytuacji - odpływ zasobów ludzkich. W pierwszym przypadku mamy wzrost populacji, lokatę w wiedzęi większą efektywność regionalną. Następstwem tej sytuacji jest wzrost gospodarczy i regionalny (Faggian, McCann, 2009). 
W rozwoju regionu oraz w teoriach lokalizacji kapitał społeczny traktowany jest jako ten element, który ma wpływ na rozwój. Precyzyjne odniesienie w tej kwestii można znaleźć w teorii biegunów wzrostu autorstwa F. Perrouxa. Według tego badacza, natężenie nie występuje wszędzie w sposób jednakowy, ma różną siłę w rozmaitych obszarach i punktach wzrostu. Następnie rozchodzi się z różnym przebiegiem i zróżnicowanymi skutkami dla regionu. Koncepcja ta kładzie nacisk na zmiany, których przekaźnikiem jest czynnik ludzki (Grzeszczak, 2007).

A. Hirschman w teorii rozwoju nierównomiernego twierdzi, że wzrost w określonej sferze jest niezrównoważony, gdyż jest zależny od czynników lokalizacyjnych i związanych z nimi korzyści bądź ograniczeń. Równocześnie uwzględnia w rozwoju gospodarczym podłoże psychologiczne. Twierdzi, że ważnym elementem w rozwoju regionu jest charakter społeczności lokalnej (Hirschman, 1958).

Teoria centrum i peryferii J. Friedmanna zwraca się w stronę czynnika ludzkiego jako komponentu wpływającego na rozwój regionu. Powstała ona na podstawie teorii rozwoju nierównomiernego i zakłada, że aktywizacja regionalna powinna być zależna od czynników pozaekonomicznych, związanych z człowiekiem. Procesy, które zachodzą w danej dziedzinie, mają związek z działalnością człowieka, co wpływa na innowacyjność i rozrost regionów. Elementy te wymagają jednak wiedzy i kapitału społecznego (Friedmann, 1966).

Z kolei według M. Herbsta istnieje współzależność pomiędzy potencjałem kapitału społecznego a możliwościami rozwojowymi regionów w Polsce. Te obszary, które w latach 90. XX w. odznaczały się wysoką wartością wiedzy oraz efektywnością, w następnych okresach szybko się rozwijały. Rejony o przeciwnym potencjale rozwijały się wolniej (Herbst, 2007).

Z przytoczonych przykładów z literatury wyraźnie wynika, że kapitał społeczny ma wpływ na atrakcyjność, możliwości i postępowość regionalną. Warunkiem rozwoju danego obszaru jest jakość tego kapitału, jego płaszczyzna naukowa, poziom adaptacji i stałości społecznej. Warto zaznaczyć, że zasadniczą cechą zasobności ludzkiej jest dążenie do komasacji przestrzennej. Oczywistym jest, że największa centralizacja następuje w stolicach regionów, które są równocześnie skupiskami kapitału społecznego o najwyższym potencjale.

\section{Kapitał społeczny a rozwój przedsiębiorczości regionalnej województwa małopolskiego}

Kapitał społeczny nieodłącznie wiąże się z wyborem właściwych wzorów pomiaru. W przypadku tego rodzaju zasobu pojawia się utrudnienie w postaci jego niematerialności. Aby móc w sposób odpowiedni ułożyć elementy kapitału społecznego, należy wziąć pod uwagę metody, które służą jego pomiarowi. Zaliczamy do nich: metody finansowe, czyli takie, które wyraża się w postaci pieniężnej, oraz metody jakościowe, czyli pokazujące czynniki, które mają wpływ na określone zmiany. Z pierwszym rodzajem metod są związane: obszary ochrony zdrowia człowieka, rozwój zawodowy i kształcenie, programy studiów, zasięg migracji oraz sytuacja ekonomiczna i rozwojowa firm. Na drugi rodzaj metod składają się wskaźniki i współczynniki, takie jak wskaźnik skolaryzacji. Bardzo często mierniki kapitału społecznego obejmują informacje z rynku pracy, m.in. współczynnik aktywności zawodowej i wskaźnik zatrudnienia (Makuch, 2014). Atrakcyjność regionu ma wielowymiarowy charakter, na który składa się wiele zmiennych, będących podstawą oceny społeczno-ekonomicznej danego obszaru. 
Na podstawie dysertacji organizacji badawczych można stwierdzić, że województwo małopolskie od wielu lat cechuje się wysoką atrakcyjnością wśród innych województw. W raporcie Instytutu Badań nad Gospodarką Rynkową z 2016 r. Małopolska plasuje się na czwartym miejscu pod względem przedsiębiorczości inwestycyjnej (za województwami śląskim, mazowieckim i dolnośląskim). Największymi atutami województwa są duże zasoby pracy przy dość korzystnych wynagrodzeniach oraz bardzo dobrze rozwinięta infrastruktura społeczna i duży rynek zbytu (ryc. 1).

Na przestrzeni pięciu lat atrakcyjność województwa małopolskiego nie zmieniła się. Niewielki wzrost można było zaobserwować w roku 2015, co być może związane było z oddaniem do użytku w 2014 r. kolejnego odcinka autostrady A4 na odcinku Tarnów-Północ

Ryc. 1. Atrakcyjność województwa małopolskiego w 2016 r.

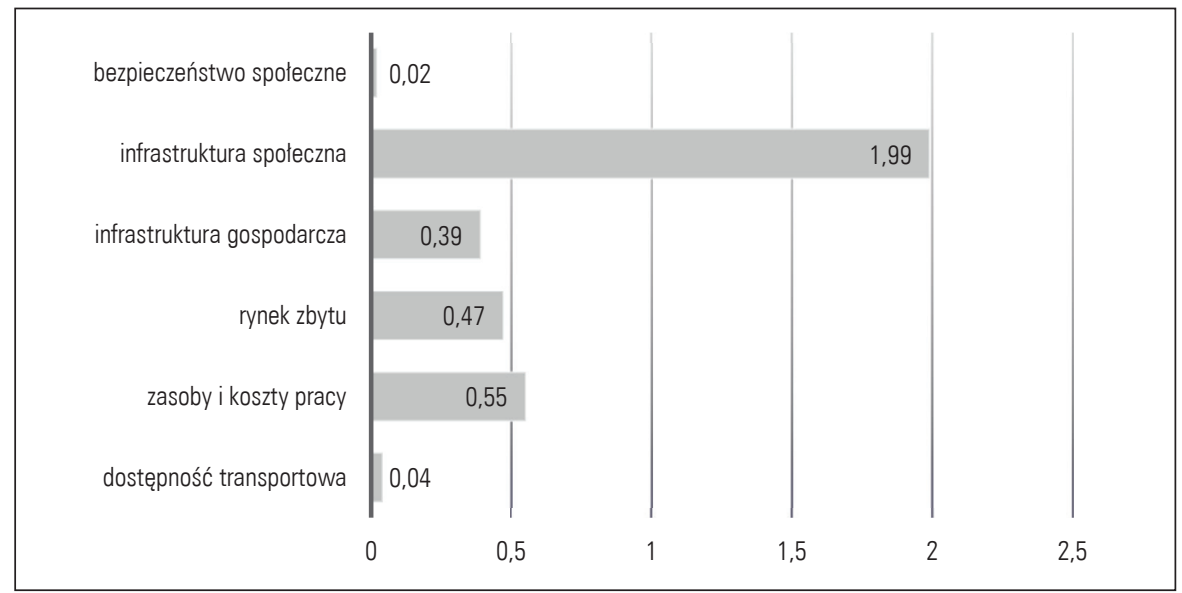

Źródło: opracowanie własne na podstawie: Instytut Badań nad Gospodarką Rynkową (2016)

Ryc. 2. Zmiana atrakcyjności województwa małopolskiego w latach 2012-2016

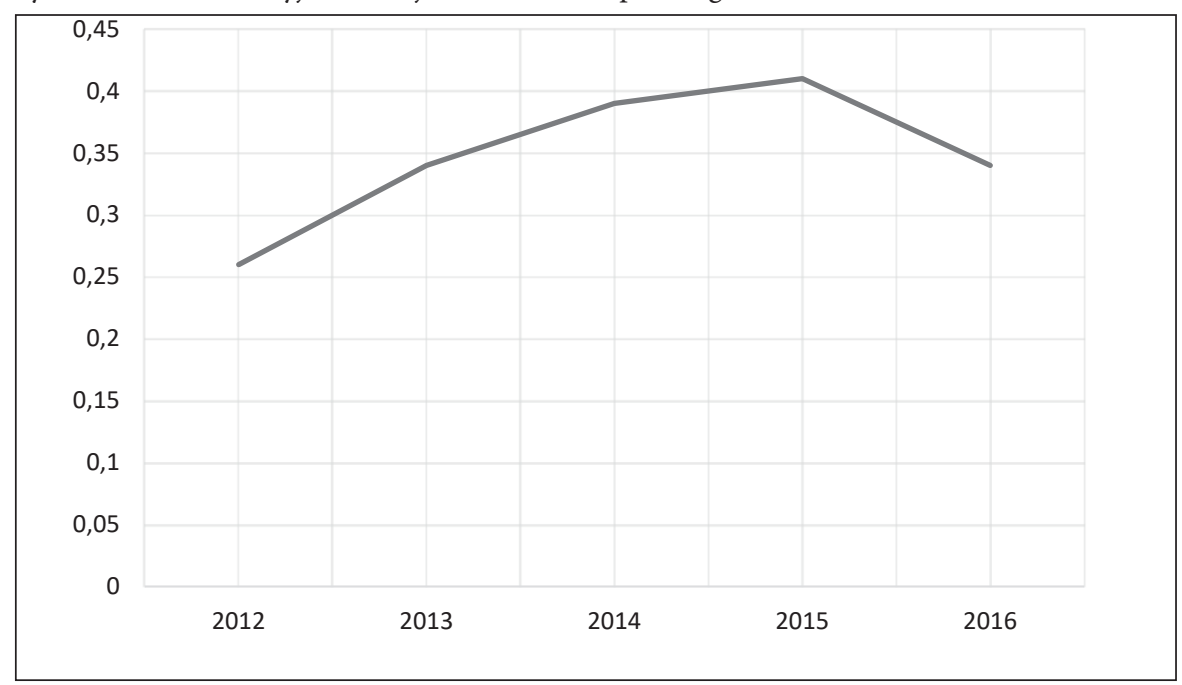

Źródło: opracowanie własne na podstawie: Instytut Badań nad Gospodarką Rynkową (2016) 
- Dębica-Wschód. Ten kierunek mógł spowodować wzrost dostępności transportowej nie tylko w obszarze ekonomicznym, ale także w obszarze społecznym (ryc. 2).

Do zbadania atrakcyjności regionu małopolskiego, czyli zdolności do rozwoju przez oferowanie kombinacji korzyści, które są możliwe do osiągnięcia i wynikają ze specyficznych cech regionu, autorka publikacji wybrała sześć obszarów związanych z kapitałem społecznym. Były to: dostępność transportowa, zasoby i koszty pracy, rynek zbytu, infrastruktura gospodarcza, infrastruktura społeczna i bezpieczeństwo społeczne. Dane zostały zaczerpnięte z opracowania Instytutu Badań nad Gospodarką Rynkową Atrakcyjność inwestycyjna województw i podregionów Polski w 2016 roku. W badaniach została wykorzystana procedura klasyfikacji pseudojednocechowej, co wpływa na względny charakter danych. Wzorcem była wartość średnia dla zestawienia województw i podregionów.

Rola dostępności transportowej w aspekcie kapitału społecznego jest związana z warunkami transportu pasażerskiego dla potrzeb rozwoju regionu. Uwzględnia się również znaczenie węzłów komunikacyjnych dla zmian przedsiębiorczych.

Zasoby i koszty pracy mają silny związek z zatrudnieniem oraz poziomem wykształcenia ludzi. Odpowiednia liczba pracowników, którzy posiadają odpowiednie wykształcenie oraz właściwe umiejętności, podnosi wartość regionalną. Po dodaniu do tego cech osobistych pracownika (takich jak odpowiedzialność, uczciwość, sumienność) pojawia się obszar z wykwalifikowaną kadrą, czyli odpowiednim kapitałem.

Rynek zbytu kształtuje rozwój regionu i wyznacza drogi jego przyrostu. Im jest on większy, tym istnieje większa możliwość ograniczenia kosztów finalnych przez redukcję kosztów transportu.

Infrastruktura gospodarcza jest związana z funkcjonowaniem i realizacją różnorodnych inwestycji. Na rozwój przedsiębiorczości regionalnej mają wpływ nie tylko instytucje biznesowe, ale także naukowo-badawcze, czyli powiązane z kapitałem społecznym.

Infrastruktura gospodarcza ma bezpośredni związek z kapitałem społecznym i wpływa na ekspansywność regionalną. Dzięki korzystnym warunkom życia, odpowiedniej wielkości i jakości potencjału zatrudnienia oraz otwartości w poglądach, region staje się innowacyjny, otwarty i przedsiębiorczy.

Ostatni wybrany wskaźnik to bezpieczeństwo społeczne. Jego rola związana jest z poczuciem bezpieczeństwa osobistego i osób z bliskiego sąsiedztwa. Niski poziom tego miernika wpływa na zwiększenie wydatków na ochronę, ale także na zmniejszenie się zasobów siły roboczej w wyniku migracji. Poziom bezpieczeństwa zależy głównie od jakości zasobów ludzkich.

Atrakcyjność województwa małopolskiego w obszarze działalności przemysłowej pozwala temu regionowi mieścić się w czołowej piątce regionów. Największe znaczenie dla jego rozwoju mają zasoby i koszty pracy, rynek zbytu oraz infrastruktura społeczna (ryc. 3). W tym przypadku największą zaletą tego miejsca jest bardzo duża liczba osób zatrudnionych, szacowana na 1,44 $\mathrm{mln}$ osób $^{2}$. Liczba pracujących osób oraz struktura zatrudnienia jest zmienna i zależna od sezonu.

$\mathrm{Z}$ analizy ryciny 4 wynika, iż najliczniej reprezentowane były grupy osób w wieku 25-34 lata oraz 35-44 lata (odpowiednio: 29,0\% i 26,7\% ogółu). Natomiast najmniej liczne były grupy wiekowe 15-24 lata oraz 55 lat i więcej. Ich udział w ogólnej liczbie

\footnotetext{
${ }^{2}$ Dane zbierane na podstawie badań statystyki publicznej udostępnianych przez Główny Urząd Statystyczny na podstawie Badań Aktywności Ekonomicznej Ludności (BAEL).
} 
Ryc. 3. Atrakcyjność województwa małopolskiego dla działalności przemysłowej w 2016 r.

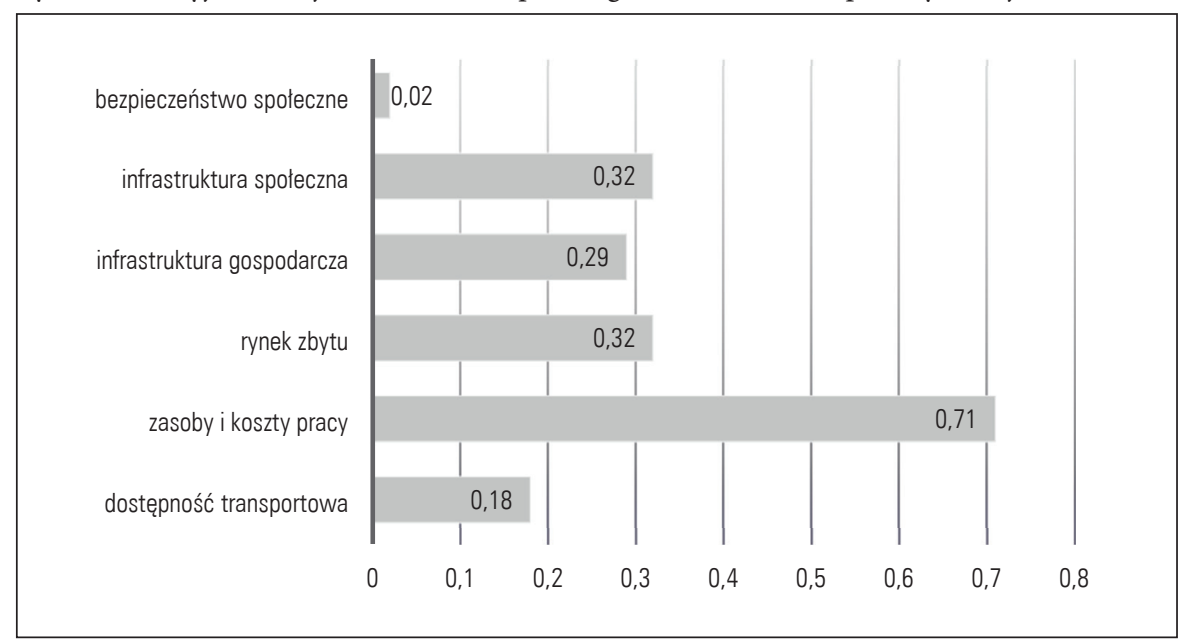

Źródło: opracowanie własne na podstawie: Instytut Badań nad Gospodarką Rynkową (2016)

Ryc. 4. Struktura zatrudnienia ludności województwa małopolskiego według wieku w 2016 r.

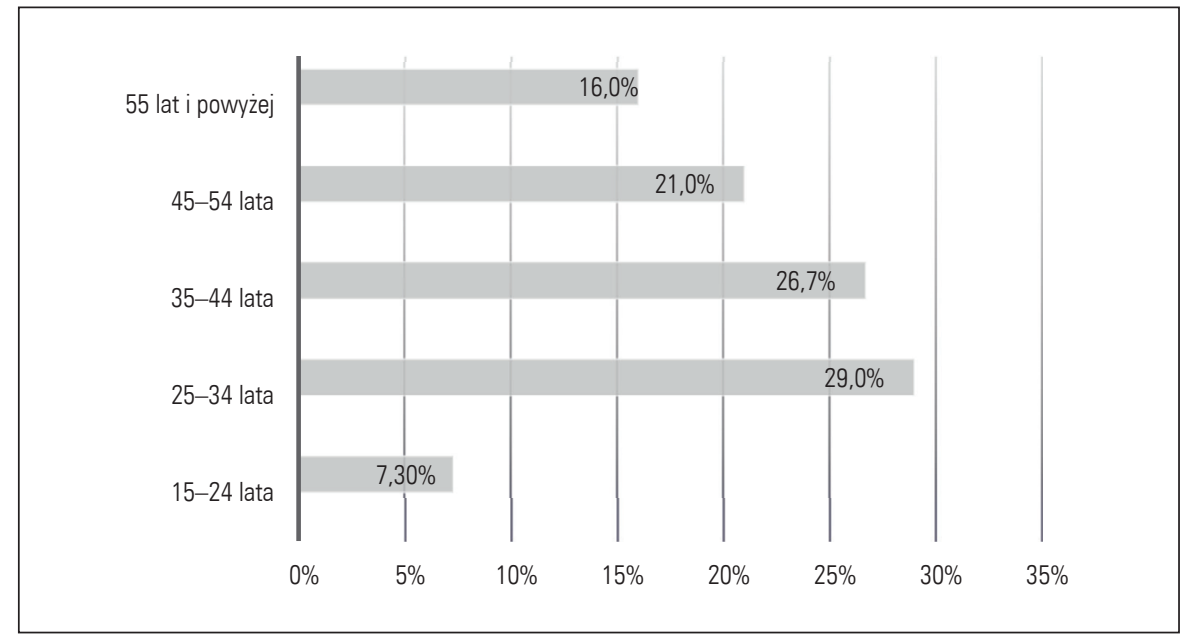

Źródło: opracowanie własne na podstawie: Instytut Badań nad Gospodarką Rynkową (2016)

pracujących w 2016 r. wyniósł odpowiednio: 7,3\% i 16\%. Wskaźnik zatrudnienia, czyli udział pracujących w ogólnej liczbie ludności w wieku 15 lat i więcej, w omawianym okresie ukształtował się na poziomie 54,4\% (tj. wyższym niż wskaźnik krajowy, który wynosił $53,2 \%)^{3}$.

Zdecydowanie najwyższą wartość w działalności usługowej mają zasoby i koszty pracy. Rynek zbytu oraz szczególnie infrastruktura społeczna są na wysokim poziomie rozwoju. Największym atutem omawianego regionu w odniesieniu do kapitału społecznego

${ }^{3}$ Badanie Aktywności Ekonomicznej Ludności w województwie małopolskim w 2016 r., opracowanie sygnalne, Kraków, marzec 2017. 
Ryc. 5. Atrakcyjność województwa małopolskiego dla działalności usługowej w 2016 r.

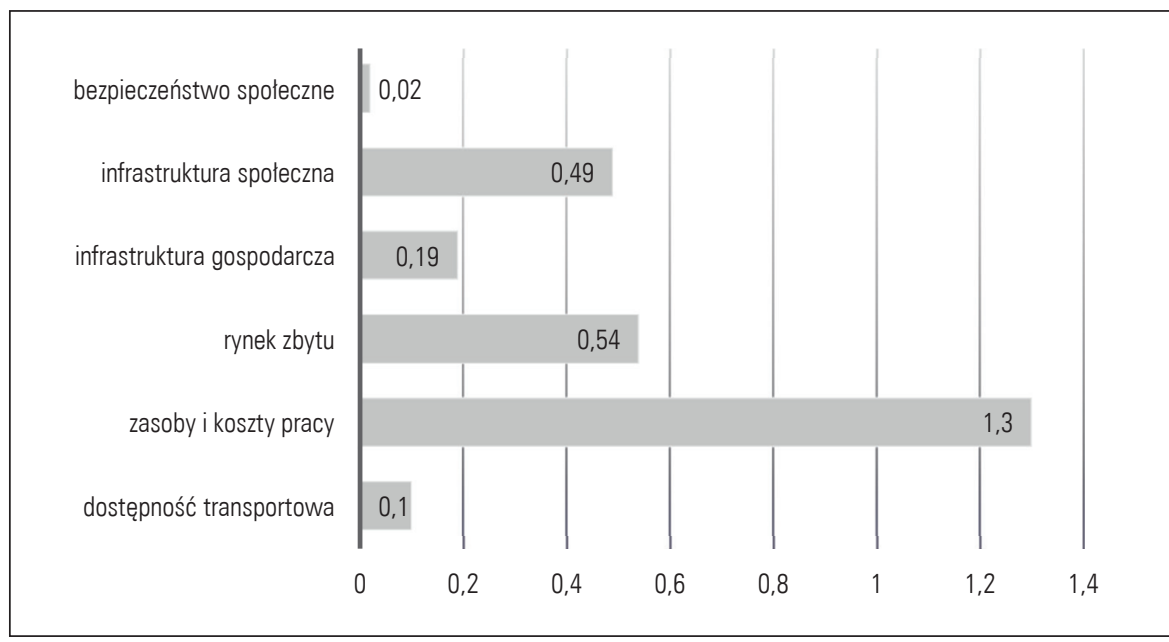

Źródło: opracowanie własne na podstawie: Instytut Badań nad Gospodarką Rynkową (2016)

Ryc. 6. Atrakcyjność województwa dla działalności zaawansowanej technologicznie w 2016 r.

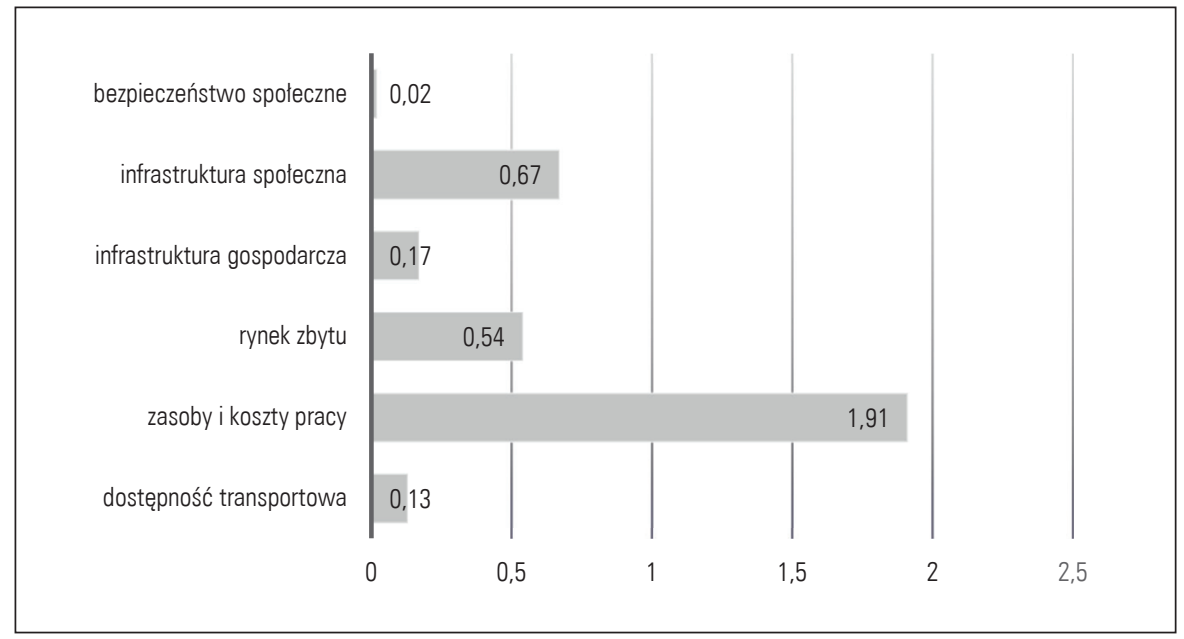

Źródło: opracowanie własne na podstawie: Instytut Badań nad Gospodarką Rynkową (2016)

jest bardzo szeroka oferta kulturalna i wysoka atrakcyjność turystyczna (ryc. 5). Dodatkowo atutami rozwojowymi województwa małopolskiego są wysoka gęstość zaludnienia (222 os. $\left./ \mathrm{km}^{2}\right)^{4}$ i współczynnik aktywności zawodowej na poziomie 56\% (dane z 2016 r.). Również poziom przedsiębiorczości (liczba podmiotów w systemie REGON w 2016 r. to 371,1 tys.) wyróżnia ten region spośród innych obszarów w Polsce.

Jeżeli weźmiemy pod uwagę atrakcyjność regionalną w obrębie działalności zaawansowanej technologii w odniesieniu do kapitału społecznego, to omawiany teren przoduje ponownie w obszarze zasobów i kosztów pracy, infrastruktury społecznej oraz rynków

\footnotetext{
${ }^{4}$ Stan z 31 grudnia 2014 r.
} 
Ryc. 7. Bezrobocie w województwie małopolskim według poziomu wykształcenia w $2016 \mathrm{r}$.

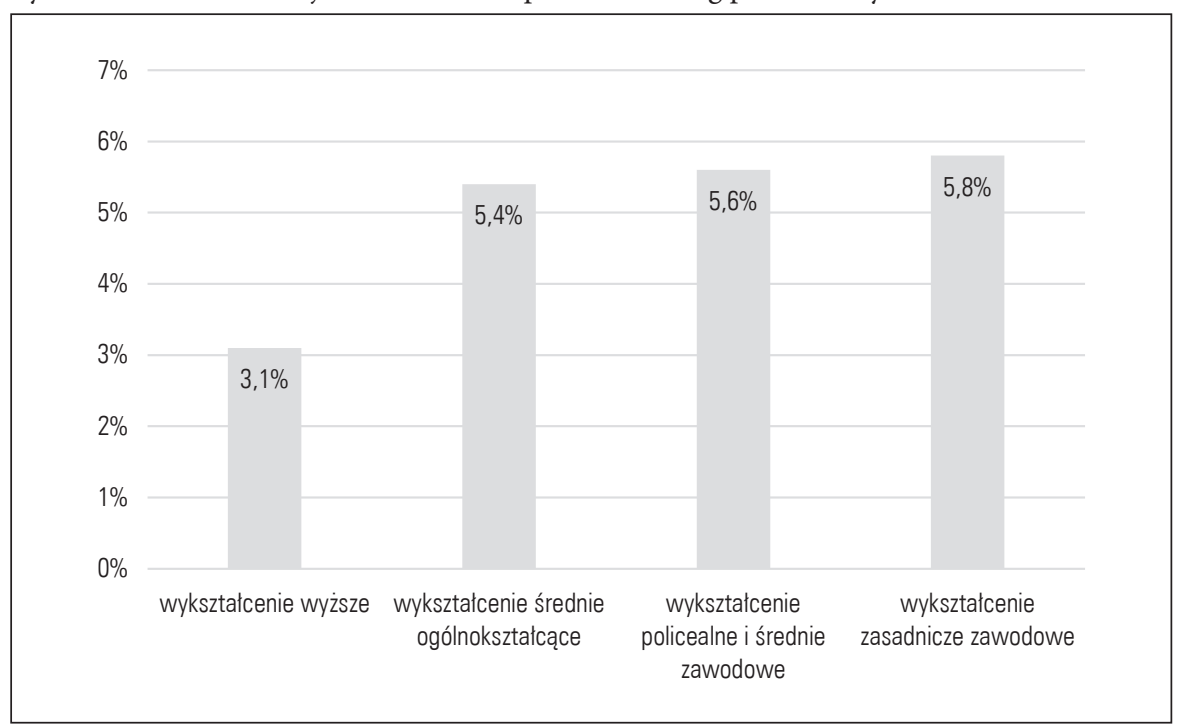

Źródło: opracowanie własne na podstawie: Główny Urząd Statystyczny (2016)

zbytu (ryc. 4). Wynikać to może z dużego zasięgu Krakowa jako jednego z najważniejszych ośrodków akademickich w Polsce, oferującego najwyższą jakość zasobów wykwalifikowanych pracowników. Potencjałem społecznym regionu są zatem wykształceni, młodzi ludzie. Gdy kończą oni edukację, są pełni energii i chęci do podjęcia odpowiednich działań zawodowych.

Możemy powołać się na dane, które są związane z wykształceniem. To ten wskaźnik najlepiej pokazuje stratę lub użycie potencjału. Zjawisko bezrobocia w województwie jest szczególnie widoczne wśród ludzi młodych. Stopa bezrobocia w grupie osób w wieku 15-24 lata w 2016 r. wyniosła 18,1\% ${ }^{5}$. Brak pracy, zwłaszcza dla ludzi młodych, jest stratą jednostkową, a także społeczną. Niszczy się rezerwuar tych, którzy posiadają nową energię (Makuch, 2014). Równocześnie w 2016, biorąc pod uwagę poziom wykształcenia, najniższą stopę bezrobocia notowano wśród osób z wykształceniem wyższym - 3,1\%, a następnie średnim ogólnokształcącym - 5,4\%, policealnym i średnim zawodowym $5,6 \%$ oraz zasadniczym zawodowym - 5,8\% ${ }^{5}$ (ryc. 7). Szczególne wymogi rynku powodują podnoszenie kwalifikacji, a co za tym idzie, zmniejszanie się bezrobocia wśród ludzi z wyższym wykształceniem.

Region małopolski pozostaje nadal w czołówce województw (z mazowieckim i dolnośląskim), gdzie potencjałem są młodzi ludzie, choć można w tym obszarze odnotować zmiany. W roku akademickim 2015/2016 w 31 szkołach wyższych mających siedzibę na terenie województwa małopolskiego uczyło się 175,6 tys. studentów. W porównaniu ze stanem z poprzedniego roku liczba studentów zmniejszyła się o 3,8\% (o 7,0 tys.) ${ }^{6}$.

\footnotetext{
${ }^{5}$ Badanie Aktywności Ekonomicznej Ludności w województwie małopolskim w 2016 r., opracowanie sygnalne, Kraków, marzec 2017.

${ }^{6}$ Urząd Statystyczny w Krakowie, opracowanie sygnalne nr 10, sierpień 2016.
} 


\section{Podsumowanie}

Zaprezentowane powyżej przykłady mierników rozwoju regionalnego opartego na kapitale społecznym w województwie małopolskim wskazują na to, iż ten zasób mocno związany jest z korzyściami, zarówno gospodarczymi, jak i z tymi, które nie muszą współistnieć z gospodarką.

W aspekcie gospodarczym wpływy z kapitału społecznego można powiązać z zasobnością jednostki i gospodarki narodowej (Obserwacje OECD, 2007). Przedstawione w artykule elementy wpływające na przedsiębiorczość regionu małopolskiego z punktu widzenia zasobów ludzkich pokazują, że w regionie potrzebna jest efektywna i skuteczna inwestycja w młode pokolenie oraz poziom życia mieszkańców. Inwestowanie w kapitał społeczny jest koniunkturą potrzebną do budowania gospodarki regionalnej opartej na wiedzy. Taki kierunek może doprowadzić do wzrostu gospodarczego i postępu (Domański, 2000).

Ważnym czynnikiem nowoczesności w regionie jest tworzenie systemu edukacji i miejsc pracy, z uwzględnieniem charakteru gospodarki regionu. Kształcenie powinno być zsynchronizowane $\mathrm{z}$ ekonomią regionu, a poziom wiedzy dopasowany do potrzeb rynku pracy. Absolwenci szkół wyższych, którzy są potencjałem regionu, winni mieć gwarancję zatrudnienia i tym samym przyczyniać się do pozytywnych przemian regionalnych.

Ranga zasobów ludzkich jest kluczowym czynnikiem produkcji w rozwijającej się kategorii gospodarki, która oparta jest na wiedzy. Pamiętać należy również o tym, iż od tego rodzaju kapitału są zależne w znacznym stopniu postęp techniczny i majątek trwały (Florczak, 2007). Silna pozycja Małopolski wśród pozostałych regionów może mobilizować do jeszcze większego inwestowania w podnoszenie poziomu życia mieszkańców, a tym samym - w poprawę przedsiębiorczości i konkurencyjności obszaru.

Zaprezentowana w artykule literatura oraz omówienie wybranych wyznaczników rozwoju regionu małopolskiego na podstawie kapitału społecznego mogą stanowić wstęp do dalszych dyskusji na temat znaczenia zasobów ludzkich w rozwoju regionalnym. Na podstawie danych statystycznych można pójść w kierunku sprawdzenia innych czynników mających wpływ na rozwój regionu lub koncentrację kapitału społecznego w innych województwach w Polsce.

\section{Literatura}

References

Audretsch, D.B., Fritsch, M. (2002). Growth Regimes over Time and Space. Regional Studies, 36(2), $113-124$.

Bartnik, K.M. (2016). Znaczenie kapitału ludzkiego i społecznego w rozwoju regionalnym na przykładzie Finlandii. Studia Oeconomica Posnaniensia, 4(6), 13-17.

Becker, G. (1962). Investment in Human Capital: A Theoretical Analysis. Journal of Political Economy, 70, 9-49.

Benneworth, P. (2004). In what sense 'regional development?' Entrepreneurship, underdevelopment and strong tradition in the periphery. Entrepreneurship \& Regional Development, 16, 439-458.

Bontis, N. (2002). World Congress on Intellectual Capital Readings. Boston: KMCI ButterworthHeinemann Press, MA.

Domański, S.R. (1993). Kapitał ludzki i wzrost gospodarczy. Warszawa: PWN. 
Domański, S.R. (2000). Kapitał ludzki, podział pracy i konkurencyjność. W: J. Bossak, W. Bieńkowski (red.), Konkurencyjność gospodarki Polski w dobie integracji z Uniq Europejską i globalizacji. Warszawa: Instytut Gospodarki Światowej SGH, 135.

Drucker, P. (1994). The Age of Social Transformation. The Atlantic Monthly, November, 53-58.

Faggian, A., McCann, P. (2009). Human Capital and Regional Development. W: R. Capello, P. Nijkamp (red.), Handbook of Regional Growth and Development Theories. Cheltenham, Northampton: Edwar Elgar Publishing, 133-148.

Florczak, W. (2007). Kapitał ludzki a rozwój gospodarczy. W: W. Welfe (red.), Gospodarka oparta na wiedzy. Warszawa: Polskie Wydawnictwo Ekonomiczne, 112.

Friedmann, J. (1966). A General Theory of Polarized Development. W: N. M. Hansen (red.), Growth Centres in Regional Economic Development. New York: Free Press.

Friedmann, J. (1972). A. General Theory of Polarized Development. In: N.M. Hansen (ed.), Growth Centres in Regional Economic Development. New York: Free Press.

Główny Urząd Statystyczny (2016). Rocznik Statystyczny Województwa Małopolskiego. Pozyskano z: https://krakow.stat.gov.pl/publikacje-i-foldery/roczniki-statystyczne/rocznik-statystyczny-wojewodztwa-malopolskiego-2016,8,13.html

Grzeszczak, J. (2007). Teoria biegunów wzrostu w warunkach polskich: przeszłość i teraźniejszość. W: J. Lach, M. Borowic, T. Rachwał (red.), Procesy transformacji społeczno-ekonomicznych i przyrodniczych struktur przestrzennych, Kraków: Instytut Geografii Akademii Pedagogicznej im. Komisji Edukacji Narodowej w Krakowie, 120-129.

Herbst, M. (red.). (2007). Kapitat ludzki i społeczny a rozwój regionalny. Warszawa: Wydawnictwo Naukowe Scholar.

Hirschman, A.O. (1958). The Strategy of Economic Development. New Haven: Yale University Press.

Huczek, M. (2011). Organizacje pozarządowe wspierające lokalną i regionalną przedsiębiorczość. Państwo i Społeczeństwo, 2, 31-57.

Huggins, R., Williams, N. (2011). Entrepreneurship and regional competitiveness: The role and progression of policy. Entrepreneurship \& Regional Development, 23(9-10), 907-932.

Instytut Badań nad Gospodarką Rynkową, (2016). Atrakcyjność inwestycyjna województw i podregionów Polski w 2016 roku. Pozyskano z: http://www.kas.de/wf/doc/kas_43988-1522-8-30. pdf?161219080952

Klasik, A. (2006). Przedsiębiorczość i konkurencyjność a rozwój regionalny. Katowice: Wydawnictwo Akademii Ekonomicznej w Katowicach.

Machlup, F. (1962). The Production and Distribution of Knowledge in United States. Princeton: Princeton University Press.

Makuch, M. (2014). Kapitał ludzki jako determinanta rozwoju społecznego. Zarys problemu z perspektywy regionu. Studia Ekonomiczne. Zeszyty Naukowe Uniwersytetu Ekonomicznego w Katowicach, $167,55-61$.

Mincer, J. (1958). Investment in human capital and personal income distribution. Journal of Politocal Economy, 66, 281-302.

Obserwacje OECD (2007). Kapitał ludzki: w jaki sposób wiedza kształtuje Twoje życie. Pozyskano z: http://www.oecd.org/dataoecd/29/6/38435854.pdf.

Petty, W. (1699). Political Arithmetic. Pozyskano z: https://www.marxists.org/reference/subject/economics/petty/

Piróg, D. (2016). Wybrane determinanty przedsiębiorczości indywidualnej - zarys stanu badań. Przedsiębiorczość - Edukacja, 12, 300-314.

Putnam, R. (1995). Demokracja w działaniu. Tradycje obywatelskie we wspótczesnych Włoszech. Kraków: Znak.

Skawińska, E. (2009). Kapitał społeczny w rozwoju regionu. W: W. Janasz (red.), Innowacje w strategii rozwoju organizacji w Unii Europejskiej. Warszawa: Difin, 48.

Schultz, T.W. (1963). The economic value of education. New York: Columbia University Press. 
Smith, A. (1954). Badania nad natura i przyczynami bogactwa narodów. Tom I. Warszawa: PWN. Strużycki, M. (2011). Przedsiębiorstwo. Region. Rozwój. Warszawa: Difin.

Zarycki, T. (2008). Dwa wymiary kapitału społecznego w kontekście polskim. Pomorski Przegląd Gospodarczy, 2(37), 49-52.

Zygmunt, J. (2015). Przedsiębiorczość jako czynnik rozwoju regionalnego na przykładzie województwa opolskiego. Prace Naukowe Uniwersytetu Ekonomicznego we Wrocławiu, 393.

Monika Borgiasz, mgr geografii, doktorantka w Instytucie Geografii Uniwersytetu Pedagogicznego, stopień magistra geografii uzyskała w 1996 r. w Wyższej Szkole Pedagogicznej w Krakowie. Ukończyła studia podyplomowe: ochrona i kształtowanie środowiska geograficznego (1997) na Uniwersytecie Jagiellońskim w Krakowie oraz przyroda (2007) w Akademii Pedagogicznej w Krakowie. Jako geograf swoje zainteresowania skierowała w stronę badań naukowych dotyczących regionu i jego tożsamości w geografii. Nowe trendy w rozwoju geografii mogą powodować zmiany w postrzeganiu regionu i jego wpływu na rozwój lokalny i regionalny. Dlatego w swoich badaniach chce pokazać powiązania i konkretne przykłady wpływu regionu na rozwój kapitału społecznego.

Monika Borgiasz, MA in Geography, PhD studies at the Pedagogical University of Cracow, Institute of Geography. She obtained her MA in Geography in 1996 at the Pedagogical University of Cracow, completed two courses of postgraduate studies - Protection and management of the geographical environment in 1997 at the Jagiellonian University in Krakow and Natural science in 2007 at the Pedagogical University of Cracow. As a geographer, in her research she is oriented towards regions and their identity in geography. New trends in geography development can cause changes in the perception of the region and its impact on local and regional development. Therefore, in her research she wants to show the links and particular examples of the region's influence on the development of social capital.

\section{Adres/Address:}

Uniwersytet Pedagogiczny im. Komisji Edukacji Narodowej w Krakowie

Instytut Geografii

Zakład Dydaktyki Geografii

ul. Podchorążych 2

30-084 Kraków, Polska

e-mail: m.borgiasz@gmail.com 